\title{
Peran Dimensi Komitmen Organisasi terhadap Intensi Turnover pada Guru SMA Swasta
}

\author{
Syarifur Ridho $^{1^{*}}$, Abd. Rasyid Syamsuri ${ }^{2}$ \\ ${ }^{1,2}$ Sekolah Tinggi Ilmu Ekonomi Labuhan Batu, Labuhan Batu \\ *syarifur.ridho@yahoo.com
}

\begin{abstract}
The commitment of the organization has an important role in supporting the organization's sustainability. Organizational commitment is divided into three dimensions. They are affective commitment, commitment and normative commitment. This study aims to examine the effect of the three dimensions of organizational commitment to turnover intention. The research was conducted at Private Senior High School in Rantaurapat City with 104 respondents. The research was analyzed by using multiple regression analysis method. The results showed that there was a negative and significant influence between affective commitment, and continuance commitment to turnover intention. However, the normative commitment dimension of the negative effect is not significant to the intention of turnover
\end{abstract}

Keywords : turn over intention, affective commitment, continuance commitment dan normative commitment.

\begin{abstract}
Abstrak
Komitmen organisasi memiliki peran penting dalam mendukung keberlangsungan organisasi. Komitmen organisasi dibagi atas tiga dimensi yaitu affective commitment, continuance commitment dan normative commitment. Penelitian ini bertujuan untuk melihat pengaruh ketiga dimensi komitmen organisasi tersebut terhadap intensi turnover. Penelitian dilakukan pada SMA Swasta yang ada di Kota Rantaurapat dengan jumlah responden sebanyak 104 guru. Penelitian dianalisis dengan menggunakan metode analisis regresi berganda. Hasil penelitian menunjukkan bahwa terdapat pengaruh yang negatif dan signifikan antara affective commitment, dan continuance commitment terhadap intensi turnover. Namun dimensi normative commitment pengaruhnya negatif tidak signifikan terhadap intensi turnover.
\end{abstract}

Kata kunci : intensi turnver, affective commitment, continuance commitment dan normative commitment.

\section{Pendahuluan}

\subsection{Latar Belakang Masalah}

Intensi turnover merupakan niat seseorang untuk meninggalkan organisasi. Woods dan Macaulay (1989) menjelaskan bahwa turnover yang tinggi pada organisasi dapat mengganggu kegiatan organisasi, menimbulkan permasalahan moral pada karyawan yang tersisa, dan juga melambungkan biaya administrasi pemrosesan perekrutan karyawan baru, tunjangan, orientasi, dan biaya peluang yang hilang karena karyawan harus mempelajari keahlian yang baru. Banyak faktor yang mempengaruhi intensi turnover, termasuk salah satunya adalah komitmen organisasi.

Allen \& Meyer (dalam Umam, 2012 : 259) menjelaskan terdapat tiga dimensi dari komitmen organisasi, yaitu :

a. Affective Commitment 
Affective Commitment berkaitan dengan hubungan emosional anggota terhadap organisasinya, identifikasi dengan organisasi, dan keterlibatan anggota dengan kegiatan di organisasi. Ketika seorang karyawan memiliki affective commitment yang tinggi, maka ia akan tetap bertahan dalam sebuah organisasi karena ia memang menginginkan hal itu

\section{b. Continuance Commitment}

Pada dimensi ini anggota organisasi memiliki kesadaran bahwa ia akan mengalami kerugian jika meninggalkan organisasi. Seorang karyawan dengan continuancecommitment yang tinggi akan terus bertahan dalam organisasi karena karyawan tersebut memiliki kebutuhan untuk menjadi anggota organisasi tersebu.

\section{c. Normative Commitment}

Karyawan dengan normative commitment yang tinggi akan terusmenjadi anggota oraganisasi karena merasa dirinya harus berada dalam organisasi tersebut (Umam, 2010: 260).

Seorang guru yang memiliki komitmen organisasi tinggi akan memiliki keterlibatan dan rasa memiliki yang tinggi terhadap organisasinya tempat guru bekerja. Komitmen organisasi yang tinggi akan membuat guru merasa nyaman, dan merasa senang dalam bekerja sehingga tidak akan ada niat dari guru tersebut untuk meninggalkan atau keluar dari pekerjaanya. Dalam penelitian ini akan diteliti bagaimana dimensi komtitmen organisi tersebut terhadap intensi turnover.

Penelitian sebelumnya oleh Sianipar \& Haryanti (2014) menyimpulkan bahwa semakin tinggi komitmen terhadap organisasi maka akan semakin rendah intensi turnover dan sebaliknya semakin rendah komitmen organisasi maka semakin tinggi juga intensi turnover.

Hasil penelitian terdahulu oleh Guntur dkk (2012) menunjukkan bahwa pengaruh komitmen organisasional mengacu pada komitmen afektif, kontinuitas dan normatif. Pengaruh komitmen afektif dan kontinuitas terhadap perawat rumah sakit swasta di Makassar Indonesia secara signifikan dan negatif. Secara parsial, komitmen afektif memiliki pengaruh negatif yang signifikan terhadap niat berpindah perawat di rumah sakit swasta di Makassar, Indonesia. Diperkuat juga dengan hasil penelitian oleh Mensah \& Kosi (2016) yang menyimpulkan bahwa continuance commitment dan normative commitment memberikan kontribusi terhadap intensi turnover, namun affective commitment tidak memberikan kontribusi yang signifikan terhadap intensi turnover. Hasil penelitian yang dilakukan oleh Rokhmah \& Riani (2005) menunjukkan bahwa komitmen afektif tidak memiliki pengaruh terhadap intensi turnover. 
JURNAL SOSIAL HUMANIORA DAN PENDIDIKAN VOL. 2 NO. 1

\subsection{Rumusan Masalah}

Berdasarkan latar belakang penelitian di atas, maka rumusan masalah dalam penelitian ini adalah sebagai berikut :

a. Sejauhmana pengaruh antara affective commitment terhadap intensi turnover pada SMA Swasta di Rantauprapat?

b. Sejauhmana pengaruh antara normative commitment terhadap intensi turnover pada SMA Swasta di Rantauprapat?

c. Sejauhmana pengaruh antara continuance commitment terhadap intensi turnover pada SMA Swasta di Rantauprapat.

\section{Metode Penelitian}

Penelitian ini dilakukan pada SMA Swasta yang ada di Kota Rantauprapat dengan jumlah sampel sebesar 104 orang guru. Penelitian dilakukan dengan menggunakan metode kuantitatif. Teknik analisis yang digunakan adalah analisis regresi berganda dengan bantuan software SPSS 23.

\section{Hasil Penelitian}

\subsection{Hasil Analisis Regresi Berganda}

Hasil analisis regresi berganda dapat dilihat pada Tabel 1 berikut ini :

Tabel 1. Hasil Analisis Regresi Berganda

\begin{tabular}{llrrrr}
\hline \multicolumn{2}{c}{$\begin{array}{c}\text { Dimensi Komitmen } \\
\text { Organisasi }\end{array}$} & \multicolumn{1}{c}{ B } & Std. Error & \multicolumn{1}{c}{ t } & Sig \\
\hline 1 & $\begin{array}{l}\text { (Constant) } \\
\text { Affective_Commitment }\end{array}$ &,,- 637 & 3,905 & 8,278 &, 000 \\
& Affect &, 310 & $-2,059$ &, 042
\end{tabular}

\begin{tabular}{lllll}
$\begin{array}{l}\text { Normative_Commitme } \\
\mathrm{nt}\end{array}$ &,- 107 &, 441 &,- 242 &, 810 \\
$\begin{array}{l}\text { Continuance_Commitm } \\
\text { ent }\end{array}$ &,- 567 &, 256 & $-2,213$ &, 029 \\
\hline
\end{tabular}

Berdasarkan Tabel 1 maka dapat dibuat persamaan yaitu $\quad \mathrm{Y}=0,673$ $+0,107+0,567+3,905$. Koefisien regresi affective commitment menunjukkan hubungan yang negatif terhadap intensi turnover pada guru SMA Swasta di Rantauprapat dengan koefisien regresi sebesar -0,673. Berarti peningkatan setiap affectivecommitmentmaka intensi turnover akan menurun sebsesar 0,637. Dengan demikian apabila affective commitment meningkat maka keinginan untuk meninggalkan organisasi juga akan menurun. Sebaliknya apabila affective commitment menurun, maka keinginan untuk meninggalkan organisasi juga akan meningkat. Hasil penelitian diperkuat oleh Widhi Putra \& Sariyathi (2017) yang menyatakan bahwa komitmen organisasi memiliki pengaruh yang negatif terhadap intensi turnover.

Koefisien regresi normative commitment menunjukkan hubungan yang negatif terhadap intensi turnover pada guru SMA Swasta di Rantauprapat dengan koefisien regresi sebesar $-0,107$. Koefisien regresi bernilai negatif menunjukkan bahwa pengaruh antara normative commitment terhadap intensi turnver memiliki arah yang negatif. Berarti peningkatan setiap normative commitment maka intensi turnover akan menurun sebsesar 0,107. Dengan demikian apabila normative commitment meningkat maka keinginan untuk 
meninggalkan organisasi juga akan menurun.

Sebaliknya apabila normative commitment menurun, maka keinginan untuk meninggalkan organisasi juga akan meningkat.

Koefisien regresi continuance commitment menunjukkan hubungan yang negatif terhadap intensi turnover pada guru SMA Swasta di Rantauprapat dengan koefisien regresi sebesar -0,567. Koefisien regresi bernilai negatif menunjukkan bahwa pengaruh antara continuance commitment terhadap intensi turnver memiliki arah yang negatif. Berarti peningkatan setiap normative commitment maka intensi turnover akan menurun sebsesar -0,567. Dengan demikian apabila continuance commitment meningkat maka keinginan untuk meninggalkan organisasi juga akan menurun. Sebaliknya apabila continuance commitment menurun, maka keinginan untuk meninggalkan organisasi juga akan meningkat.

Koefisien regresi affective commitment menunjukkan hubungan yang negatif terhadap intensi turnover pada guru SMA Swasta di Rantauprapat dengan koefisien regresi sebesar -0,673. Berarti peningkatan setiap affective commitment maka intensi turnover akan menurun sebsesar -0,637. Dengan demikian apabila affective commitment meningkat maka keinginan untuk meninggalkan organisasi juga akan menurun. Sebaliknya apabila affective commitment menurun, maka keinginan untuk meninggalkan organisasi juga akan meningkat.

Nilai konstanta sebesar 32,328 menunjukkan bahwa intensi turnover sangat ditentukan oleh affective commitment, ontinuance commitment dan normative commitment. Dengan kata lain apabila affective commitment, continuance commitment dan normative commitment bernilai 0 maka nilai intensi turnover sebesar 32,328 .

\subsubsection{Koefisien Determinasi}

Nilai R (koefisien regresi) adalah sebesar 0,583 . Nilai R berada dalam kisaran antara (-1) dan 1, sehingga nilai sebesar 0.583 termasuk mempunyai korelasi yang erat karena berada dalam kisaran tersebut. Nilai R2 (R square) sebesar 0.340 dengan Adjusted Rsquare adalah sebesar 0.320 atau 32\%, memberi makna bahwa pengaruh variable lain affective commitment, continuance commitment dan normative commitment sebesar $68 \%$.

\section{Kesimpulan}

Berdasarkan hasil penelitian menunjukkan bahwa komitmen organisasi memiliki peran penting terhadap penurunan intensi turnover. Dari tiga aspek dimensi komitmen organisasi tersebut semuanya memiliki koefisien regresi yang negatif, hal ini mengandung makna bahwa setia peningkatan affective commitment, continuance commitment dan normative 
commitment maka akan menurunkan intensi

turnover pada SMA Swasta di Rantauprapat.

Apabila diperhatikan masing-masing dimensi,

dimensi affective commitment, dan

continuance commitment memiliki pengaruh

yang signifikan terhadap intensi turnover.

Namun dimensi normative commitment

pengaruhnya tidak signifikan terhadap intensi

turnover.

\section{Daftar Pustaka}

Guntur, atll (2012) The influence of affective, continuance and normative commitments on the turnover intentions of nurses at Makassar's private hospitals in Indonesia. African Journal of Business Management Vol. 6(38), pp. 10303-10311.

Mensah, R., \& Kosi, I. (2016). Organizational Commitment and Turnover Intentions of Clinical Laboratory Scientists in Ghana, 8(2), 164-172.

Rokhmah, B. E., \& Riani, A. L. (2005). Keterkaitan antara Komitmen Afektif dengan Intensi Turnover pada Karyawan Bagian Produksi di PT. Usman Jaya Mekar Magelang. Jurnal Ilmiah Teknik Industri,4, 78-85.

Sianipar, A. R. B., \& Haryanti, K. (2014). Hubungan Komitmen Organisasi Dan Kepuasan Kerja dengan Intensi Turnover Pada Karyawan Bidang Produksi Cv. X. Psikodimensia, 13(1), 98. Retrieved from http://journal.unika.ac.id/index.php/psi/article /view/281

Widhi Putra, P. A. S., \& Sariyathi, N. K. (2017). Pengaruh Komitmen Organisasional dan Kepuasan Kerja terhadap Turnover Intention Di Cv. Bengkel Bintang Pesona Group.EJurnal Manajemen Unud, 6(2), 579-603.

Umam, K. (2012). Perilaku Organisasi. Bandung: CV Pustaka Setia 